\title{
A Mesoporous Silica-Supported Ruthenium Catalyst for Metathesis
}<smiles>C#CCOc1ccc(OC(C)I)c(C=C)c1</smiles>

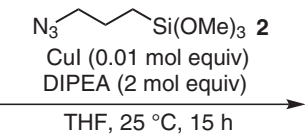

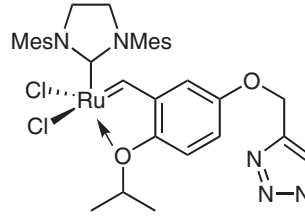
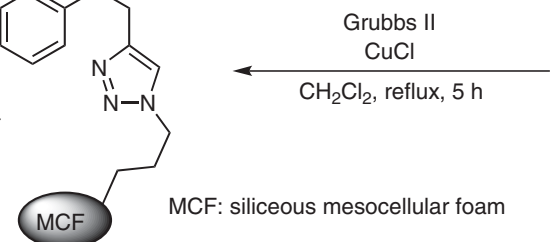

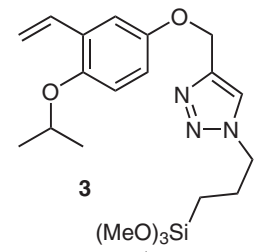

TMS-MCF (4) $\downarrow \mathrm{PhMe}, 80^{\circ} \mathrm{C}$

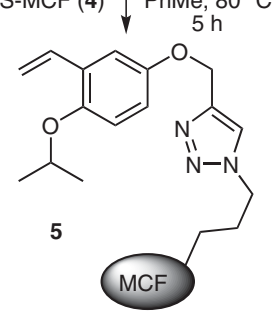

$1^{\text {st. }} 99 \%$ yield
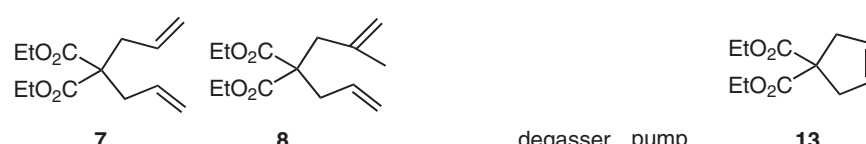
$4^{\text {th. }}: 96 \%$ yield
$7^{\text {th. }} 94 \%$ yield $10^{\text {th: }} 91 \%$ yield

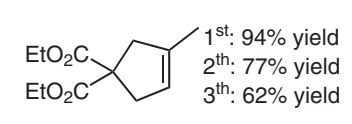<smiles>C=CCOc1ccccc1C(CC=C)OCC=C</smiles>

9

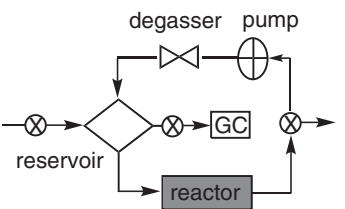

13

$1^{\text {st. }} 99 \%$ yield<smiles>CC1CC=CCO1</smiles>

: $98 \%$ yield $7^{\text {th: }} 97 \%$ yield $10^{\text {th: }}: 96 \%$ yield

15<smiles>C=CCN([AlH2])CC=C</smiles>

10<smiles>C=CCNC(=O)C(=C)C</smiles>

12

substrates

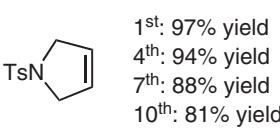

17
16

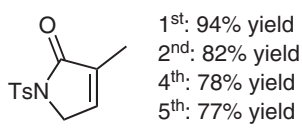

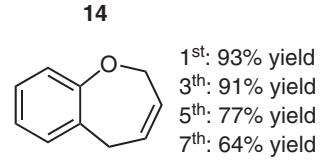

Polymer-Supported

Synthesis

Key words

mesoporous silica

metathesis

circulating flow

reactor

ruthenium

Significance: A mesoporous silica-supported catalyst 6 for metathesis was prepared and applied to a circulating flow reactor system. Thus, the Grubbs II catalyst was immobilized on siliceous mesocellular foam (MCF) microparticles 5 to give the catalyst $\mathbf{6}$. The ring-closing metathesis of dienes 7-12 was performed in a circulating flow reactor system filled with $\mathbf{6}$ (225 $\mathrm{mg}$; reactor size = $4.6 \mathrm{~mm} \times 50 \mathrm{~mm}$ ) at $50{ }^{\circ} \mathrm{C}$ with a flow rate of 5 $\mathrm{mL} / \mathrm{min}$ to afford the corresponding products 13-18 in 93-99\% yield.
Comment: The mesoporous silica-supported catalyst 6 was recycled nine times without or with loss of catalytic activity in a circulating flow reactor (15: $1^{\text {st }}$ use: $99 \%$ yield, $4^{\text {th }}$ use: $98 \%$ yield, $7^{\text {th }}$ use: $97 \%$ yield, $10^{\text {th }}$ use: $96 \%$ yield $18: 1^{\text {st }}$ use: $94 \%$ yield, $2^{\text {nd }}$ use: $82 \%$ yield, $4^{\text {th }}$ use: $78 \%$ yield). The authors mentioned that their circulating flow system was superior to the continuous flow system filled with 6 in terms of recyclability.

SYNFACTS Contributors: Yasuhiro Uozumi, Yoichi M. A. Yamada, Chung Keun Jin

DoI: 10.1055/s-0029-1219460; Reg-No.: Y01810SF 